ノート

\title{
アロエ含有食品中のバルバロイン含有量及びその安定性*1
}

(平成 9 年 3 月 29 日受理)

$\begin{array}{ll}\text { 安田和男*2 } & \text { 横山敬子*2 } \\ \text { 小川仁志*2 } & \text { 川合由華*2 }\end{array}$

\section{Barbaloin Content and Stability in Foods Containing Aloe}

\author{
Kazuo Yasuda, Keiko Yokoyama, Hirofumi Ushiy ama, \\ Hitoshi Ogawa and Yuka KawaI
}

(The Tokyo Metropolitan Research Laboratory of Public Health: 3-24-1, Hyakunin-cho, Shinjuku-ku, Tokyo 169, Japan)

The barbaloin content in 15 products containing aloe, a so-called health food, was examined. The stability of barbaloin in liquefied products and the elution rates from dried leaves and tea-bag style products infused in hot water were also investigated.

The contents of barbaloin in granulated products, powdered products and dried leaves of aloe were $2.9 \sim 5.2,5.0$ and $3.7 \sim 4.2 \mathrm{mg} / \mathrm{g}$, respectively. The contents of barbaloin in liquefied products decreased to less than $50 \%$ after storage for a month in a cold, dark place, although the $\mathrm{pH}$ remained acidic. When dried leaves were infused in hot water, most of the barbaloin was eluted into the water.

In the case of products containing large amounts of barbaloin, there is a possibility that $2 \sim 3$ times the general standard intake of them might show a cathartic effect in comparison with the content of barbaloin in the official dose of pharmacopoeial aloe.

(Received March 29, 1997)

Key words: アロエ含有食品 food containing aloe; バルバロイン barbaloin; 下剂作用 cathartic effect; 高速液体クロマトグラフィーHPLC; 薄層クロマトグラフィーTLC; 局方アロエ pharmacopoeial aloe; キダチアロエ Aloe arborescens Miller; アロエベラ Aloe barbadensis Miller

\section{緒氞}

著者らは健康食品として市販されている多種多様の食 品について，それらの安全性を評価する目的で，これま で種々の衛生学的調查を行い報告してきた ${ }^{1) 31}$. 今回は 最近, 需要が増加しているアロエを原料とする粒状及び 飲料製品等を選び，アロエの薬効成分として知られてい るバルバロインについて調査した.

アロエは古くから民間伝承薬として糖尿病, 高血圧 症, 潰瘍, やけど及び便秘などに効果があるとして用い られてきた ${ }^{4)}$.5).これらの効果については臨床的にあ 種々の研究が進み, その活性物質が明らかにされつつあ

*1 健康食品の衛生学的研究（第 4 報）

*2 東京都立衛生研究所： 169 東京都新宿区百人町 3-24-1
$ろ^{6) \sim 12)}$. それらのうちアントラキノン誘導体であるバル バロインは，アロエの持つ瀉下作用を示す主要成分であ る ${ }^{13)}$. その化学構造式を Fig. 1 に示した.<smiles></smiles>

Fig. 1. Chemical structure of barbaloin 
消費者のうち，アロエ含有食品に対し整腸作用や健胃 作用を期待して利用する人々にとっては，適量のバルバ ロインを含む製品は健康美容食品的なイメージがあるも のと思われる. しかし, 胃腸の潰瘍や炎症に対しアロエ の多糖体によると言われる61.7) 治療的効果を期待する 人々にとっては, 下剤作用を示すバルバロインは, 副作 用的効果を示す不要な成分となる.

いずれの場合も製品中にバルバロインが多量に含有さ れていると，消費者にとっては予想外の効果を受けるこ とが考えられる。

そこで現在，健康食品として市販されているアロエ含 有食品の品質を評価する目的で, 製品中のバルバロイン の含有量及びその安定性などの調査の他, バルバロイン 含有量と摄取量を比較して下剂作用の発現の可能性につ いてあ考察したので報告する.

\section{実験方法}

\section{1. 試料}

都内デパートなどで健康食品として市販されていたア ロエ含有食品のうち, 乾燥葉製品（アロエ葉を長さ 2 $4 \mathrm{~cm}$ に細切し, 乾燥させたもの) 2 試料, 混合乾燥葉 製品（アロエ及びウーロン茶の乾燥葉を混合させたす の） 1 試料, 粒状製品（アロエの乾燥葉を粉末にし, 直 径約 $5 \mathrm{~mm}$, 高さ約 5 7 $\mathrm{mm}$ に成型したもの) 6 試料, 粉末状製品（アロエの乾燥葉を粉末にしたあの）1 試 料, ティーバッグ状製品（アロエ及び他の植物の乾燥葉 を細切し, 封入したもの) 3 試料及び液状製品（清涼飲 料水の屯の) 2 試料の計 15 試料を用いた. これらの使 用方法は製品の表示によれば, 乾燥葉製品及びティー バッグ状製品は熱湯を注ぎ浸出あるいは煮出して飲用 し, 粒状及び粉末状製品は 1 日 5 粒程度あるいはス プーン 1 杯程度を摄取するようになっている。これら 製品の原料であるアロエの種類は, 製品に記載された表 示には液状製品の 1 試料で「アロエベラ」の表示が見 られたほかは, いずれあ「キダチアロエ」の表示が見ら れた。

\section{2. 試薬}

バルバロイン標準溶液：バルバロイン（ナカライテス ク(株)製，生薬試験用 $98.0 \%$ ）をシュウ酸一メタノール 溶液に溶解し, 適宜, 一定濃度として用いた。

アロエ：(株)小城忠治商店製, 日本薬局方品

アロエ末：森川久薬品（株)製, 日本薬局方品

アロイン：ナカライテスク（株)製

シュウ酸一タノール溶液：シュウ酸 $0.02 \mathrm{~g}$ をメ夕 ノールに溶解して $100 \mathrm{~mL}$ とした.

薄層クロマトグラフィー用プレート：HPTLC Fertigplatten Kieselgel 60 (Merck 社製) を用いた.

$\mathrm{C}_{18}$ カートリッジ: Sep-Pak $\mathrm{C}_{18}$ カートリッジ（Waters 社製)を, あらかじめメタノール $20 \mathrm{~mL}$, 次に水 $10 \mathrm{~mL}$ で洗浄後, 使用した.
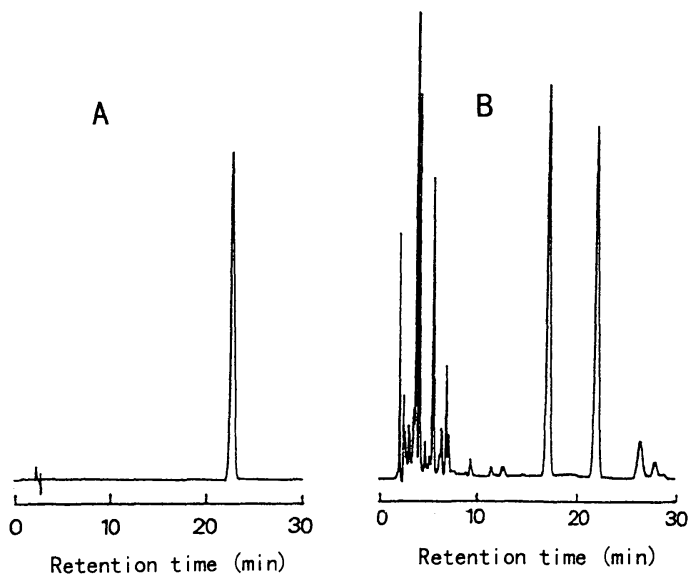

Fig. 2. HPLC Chromatograms of the extract of granulated product containing aloe

A: standard of barbaloin

B: extract of granulated product containing aloe

\section{3. 装置}

高速液体クロマトグラフ：(株) 島津製作所製 LC-6 $\mathrm{AD} ;$ フォトダイオードアレイ検出器：(株)島津製作所 製 SPD-M6A

\section{4. 試験溶液の調製}

山本ら ${ }^{14)}$ 15) の方法に準じた.

HPLC 用試験溶液は試料約 $1 \mathrm{~g}$ を精ひょうし，シュウ 酸一メ夕ノール溶液 $50 \mathrm{~mL}$ を加えた後, 超音波により 10 分間抽出した. 上澄液をメンブランフィルター $(0.45$ $\mu \mathrm{m})$ でろ過し，ろ液を試験溶液とした。

TLC 用試験溶液は試料約 $1 \mathrm{~g}$ を精ひょうし，水 50 $\mathrm{mL}$ を加えホモジナイズ後, 遠心分離（4,000 rpm, 5 分間）した. 上澄液を $\mathrm{C}_{18}$ カートリッジに負荷し, 水 $20 \mathrm{~mL}$ で洗浄後, シュウ酸一メタノール溶液 $2 \mathrm{~mL}$ で溶 出したものを試験溶液とした.

\section{HPLC 条件}

カラム: Inertsil ODS-2 $(4.6 \mathrm{~mm}$ i.d. $\times 250 \mathrm{~mm})$

移動相：水一アセトニトリルーリン酸 $(80: 18: 1)$

流速： $1.5 \mathrm{~mL} / \mathrm{min}$; カラム温度： $35^{\circ} \mathrm{C}$

検出波長: $358 \mathrm{~nm}$

\section{TLC 条件}

試験溶液 $5 \mu \mathrm{L}$ をシリカゲル薄層プレートに塗布し, クロロホルムーメタノールー水 $(65: 35: 10)$ 混液の下層を 用いて展開した. プレートを風乾後, $2 \mathrm{~mol} / \mathrm{L}$ 水酸化 ナトリウムを噴霧し増蛍光した後, 紫外線 $(365 \mathrm{~nm})$ 照 射下でスポットの蛍光を観察し，同様に操作した局方ア ロエ，バルバロイン標準品及びキダチアロエ葉抽出物の 蛍光スポットの $R f$ 值及び色調と比較して判定した. 
Table 1. Contents of Barbaloin in Foods Containing Aloe

\begin{tabular}{lcc}
\hline Sample & $\begin{array}{c}\text { No. of } \\
\text { samples }\end{array}$ & $\begin{array}{c}\text { Contents } \\
(\mathrm{mg} / \mathrm{g})\end{array}$ \\
\hline Dried leaves product & 2 & $3.7,4.2$ \\
Mixed leaves product ${ }^{\mathrm{a})}$ & 1 & 0.47 \\
Granulated product & 6 & $2.9 \sim 5.2$ \\
Powdered product & 1 & 5.0 \\
Tea bag product ${ }^{\mathrm{b})}$ & 3 & $0.27 \sim 0.90$ \\
Liquefied product $^{\text {Siqued }}$ & 2 & $\mathrm{ND}, \mathrm{ND}$ \\
\hline
\end{tabular}

ND; Not detected

a) Mixture of dried leaves of aloe and oolong tea

b) Dried leaves of aloe, oolong tea, Eucommia ulmoides (Totyuu) and Coix lacryma-jobi (Hatomugi) were put into a bag.

\section{結果及び考察}

\section{HPLC によるバルバロインの定量}

バルバロイン標準品及び試料の代表例として粒状製品 抽出液の HPLCクロマトグラムを Fig. 2 に示した.

バルバロインは溶液中ではラセミ化を起こし ${ }^{16)}$, 非常 に不安定であるが，シュウ酸を添加することにより安定 化するため*3，標準品の溶解及び試料の抽出にはシュウ 酸一メタノール溶液を用いた。

試験溶液のクロマトグラム上における 17 分付近の ピークについては, 他の報告 ${ }^{15) ~ 18) ~}$ 之同様の HPLC 分析 条件下での結果と比較したところ, バルバロインとの相 対保持時間及び存在比 (1:1) からバルバロインの異性体 であるイソバルバロインと推察した。

HPLCにより定量した各試料中のバルバロイン含有 量をTable 1 に示した.「キダチアロエのみを原料と し，製造した」との表示がある粒状製品では $2.9 〜 5.2$ $\mathrm{mg} / \mathrm{g}$, 粉末製品では $5.0 \mathrm{mg} / \mathrm{g}$, 乾燥葉製品では 3.7 及び $4.2 \mathrm{mg} / \mathrm{g}$ と, 他の製品と比較して高い值を示し た。アロエの他にウーロン茶も混合された乾燥葉製品で は $0.47 \mathrm{mg} / \mathrm{g}$ 及びその他杜仲葉及びハトムギなどが 混ったティーバッグ製品では $0.27 〜 0.90 \mathrm{mg} / \mathrm{g}$ と低い 值であった。液状製品は 2 試料とあ「アロエの葉内部 のゲル状部位を使用した」との表示のある製品で, バル バロインはいずれの試料であ検出しなかった。 なお，液 状製品のうちの 1 試料では原料アロエは「アロエベラ」 であることが表示されていた。

また，HPLCクロマトグラム上で検出されたバルバ ロインのピークについて, フォトダイオードアレイ検出 器を用い，紫外部吸収スペクトルを観察した。 バルバロ インを検出した試料について紫外部吸収スペクトルを測 定したところ，いずれも 290 及び $360 \mathrm{~nm}$ 付近に極大 波長が観察され，バルバロイン標準品のそれと一致し

*3 嶋田康男, 山本邦彦, 今西俊恵：日本生薬学会 35 年会要 旨集 A-23 (1988)

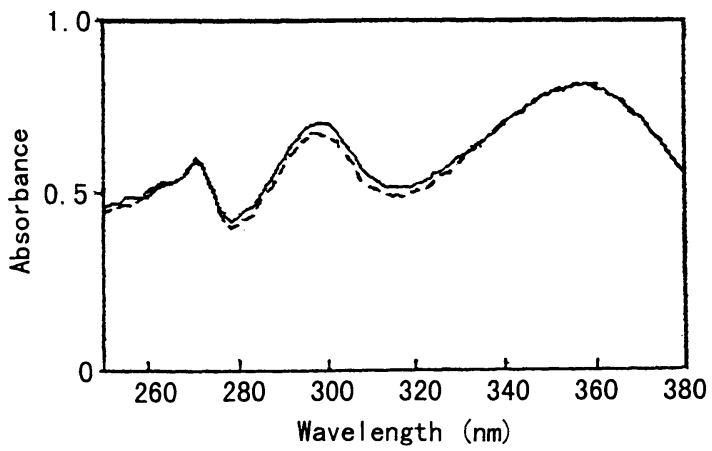

Fig. 3. Absorption spectra of the extract of granulated product containing aloe - standard of barbaloin ----: extract of granulated product containing aloe

た。代表例として粒状製品の紫外部吸収スペクトルを Fig. 3 に示した.

なお，局方アロエ中のバルバロイン含有量は $57 \mathrm{mg} /$ $\mathrm{g}$ であった。

\section{TLCによる原料アロエの種類判別}

山本ら ${ }^{19)}$ はアロエ含有キャンディーに用いられたア ロエ素材の種類をTLCクロマトグラムにより判別し, 医薬品であるアロエ末（又はアロイン）を素材として使 用しているものがあったことを報告している.

日本薬局方に収載されている「アロエ」及び「アロエ 末」は,「主として Aloe ferox Miller 又はこれと Aloe africana Miller 又は Aloe spicata Baker との雑種の葉 から得た液斗を乾燥したあのあるいは粉末としたもの」 とされている20).この「アロエ」は薬事法における「医 楽品の範囲に関する基準」21) の中で「1-a その成分本質 が専ら医薬品として使用されるむの」と判定されている ことから, 食品への利用は好ましくないと判断されてい る.一方, キダチアロエ (Aloe arborescens Miller) は 薬事法では「2-a その成分本質が通常の食生活において 
Table 2. Stability of Barbaloin in Liquefied Products Containing Aloe

\begin{tabular}{|c|c|c|c|c|}
\hline \multirow{2}{*}{ Place of storage ${ }^{a)}$} & \multirow{2}{*}{$\begin{array}{l}\text { Added } \\
(\mu \mathrm{g} / \mathrm{g})\end{array}$} & \multicolumn{2}{|c|}{ Found $(\mu \mathrm{g} / \mathrm{g})$} & \multirow{2}{*}{$\begin{array}{c}\text { Exude rate } \\
(\%)\end{array}$} \\
\hline & & Sample $\mathrm{A}^{\mathrm{b})}$ & Sample $B^{c)}$ & \\
\hline \multirow[t]{2}{*}{ Light (room temperature) } & 50 & ND & ND & 0 \\
\hline & 5 & ND & ND & 0 \\
\hline \multirow[t]{2}{*}{ Dark (room temperature) } & 50 & ND & 1.8 & 3.6 \\
\hline & 5 & ND & ND & 0 \\
\hline \multirow[t]{2}{*}{ Cold $\left(4^{\circ} \mathrm{C}\right)$ and dark } & 50 & ND & 24 & 48 \\
\hline & 5 & ND & 1.9 & 38 \\
\hline
\end{tabular}

ND: Not detected

a) The period of storage was a month.

b) The $\mathrm{pH}$ was 7.4 .

c) The $\mathrm{pH}$ was 4.2 .

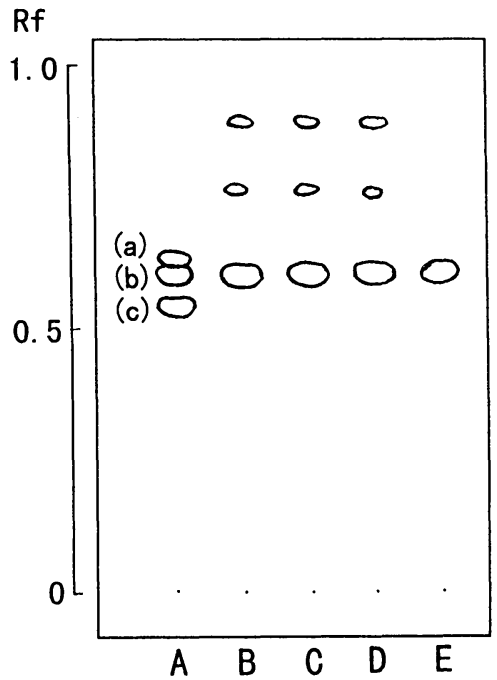

Fig. 4. Thin-layer chromatograms of the extract of dried leaves and granulated product containing aloe

A: pharmacopoeial aloe

B: dried leaves product

C: granulated product

D: extract of Aloe arborescens Miller

$\mathrm{E}$ : standard of barbaloin

(a): blue fluorescence

(b): orange-yellow fluorescence

(c): blue-white fluorescence

Developing solvent: $\mathrm{CHCl}_{3}-\mathrm{MeOH}-$ water $(65: 35: 10)$

After development, the plate was air-dried, sprayed with $2 \mathrm{~mol} / \mathrm{L} \mathrm{NaOH}$ and fluorescent spots were detected UV light at $365 \mathrm{~nm}$.

食品の範囲と認められないもの」として食品としての認 識は十分ではないが，直ちに医薬品には該当しないとさ れている. また，アロエベラ (Aloe barbadensis Miller)
はアントラキノン類を含有しない葉内ゲル状部位が「2a」として分類されており, 最近, この部位を用いた ヨーグルトやジュースなどの製品が多く市販されてい る.

そこで，今回試料としたアロエ含有食品について原料 アロエの種類をTLCにより調查した. 乾燥葉及び粒状 製品抽出液の TLC クロマトグラムを Fig. 4 に示した. 同時に, 当所敷地内より採取したキダチアロエの全葉か ら得た抽出物についても試験した。

その結果, 局方アロエでは $R f=0.6$ 付近にバルバロ インの橙黄色の蛍光スポットが認められ, 隣接した付近 にあ特徴的なそれぞれ青色及び青白色に光るスポットが 観察された.

キダチアロエ葉抽出物ではバルバロインの他に $R f=$ 0.80 及び 0.95 付近にスポットが見られた。乾燥葉及び 粒状製品抽出液のクロマトグラムではキダチアロエ葉抽 出物と同様のスポットが認められ, 原料にはキダチアロ エが使用されていることが分かった.

「原料にはアロエベラのゲル状部位を使用」と表示の ある飲料製品ではバルバロインのスポットは認められな かった。

これら以外の試料ではいずれあバルバロインを検出 し，TLCクロマトグラムにおけるその他のスポットも キダチアロエと同様のパターンを示し，局方品の「アロ エ」あるいは「アロエ末」を原料に使用したあのは見ら れなかった。

\section{3. 飲料製品におけるバルバロインの安定性}

今回調査した液状製品は, アロエの葉内部のゲル部分 を用いた製品であったため，バルバロインを検出しな かったものと思われるが, 最近, 葉を皮ごと利用してバ ルバロインの効果を期待させた飲料製品も市販されるよ うになった。しかし，バルバロインは溶液状態ではかな り不安定である*3 ため, 消費者が全部を飲み終わるま でにある程度の期間が経過した場合, 製品中のバルバロ インが消失している可能性む考えられる。 そこで, 飲料 
Table 3. Exude Rate of Barbaloin in Foods Containing Aloe during Infusing in Hot Water

\begin{tabular}{lccc}
\hline \hline Sample & $\begin{array}{c}\text { Volume of } \\
\text { sample }\end{array}$ & $\begin{array}{c}\text { Infusing } \\
\text { condition }\end{array}$ & $\begin{array}{c}\text { Exude rate } \\
(\%)\end{array}$ \\
\hline Dried leaves product A & $2 \mathrm{~g}$ & $90^{\circ} \mathrm{C}, 300 \mathrm{~mL}, 5 \mathrm{~min}$ & 75 \\
Dried leaves product B & $2 \mathrm{~g}$ & $90^{\circ} \mathrm{C}, 300 \mathrm{~mL}, 5 \mathrm{~min}$ & 90 \\
Dried leaves product C & $10 \mathrm{~g}$ & Boiling, $500 \mathrm{~mL}, 2 \mathrm{hr}$ & 67 \\
Tea bag product & $1 \mathrm{bag}(5 \mathrm{~g})$ & $90^{\circ} \mathrm{C}, 1000 \mathrm{~mL}, 8 \mathrm{~min}$ & 80 \\
\hline
\end{tabular}

製品中のバルバロインの安定性を調査した.

2 種の飲料製品（A 及び B 製品）に対しアロイン （バルバロイン含有量； $140 \mathrm{mg} / \mathrm{g}$ ）をバルバロインと して $50 \mu \mathrm{g} / \mathrm{g}$ 及び $5 \mu \mathrm{g} / \mathrm{g}$ の濃度となるように添加し て, 室内の明所 (室温), 暗所 (室温) 及び冷暗所 (冷 蔵庫内, $\left.4^{\circ} \mathrm{C}\right)$ の 3 か所に 1 か月間保存したときの, バ ルバロインの安定性を Table 2 に示した. なお, A. 製 品の $\mathrm{pH}$ は 7.4, B 製品の $\mathrm{pH}$ は 4.2 であった.

1 か月後の含有量は, $\mathrm{A}$ 製品の場合はいずれの添加量 及び保存場所であバルバロインは残存していなかった. $\mathrm{B}$ 製品の場合は, 室温の明所ではバルバロインは残存せ ず，暗所では $50 \mu \mathrm{g} / \mathrm{g}$ の濃度の場合のみ $3.6 \%$ が残存 していた．冷暗所では $5 \mu \mathrm{g} / \mathrm{g}$ の濃度の場合は $38 \%$ の 残存率であり, $50 \mu \mathrm{g} / \mathrm{g}$ の場合であ $48 \%$ と $50 \%$ 以下 の残存率であった．このことから飲料製品中のバルバロ インは, 室温放置ではすみやかに減少すること, また, 酸性状態の方が比較的安定であることが確認された.

\section{4. 熱湯浸出によるバルバロインの挙動}

乾燥葉製品あるいはティーバッグ製品は熱湯を注いで 飲用するが，その場合，製品中に含まれるバルバロイン がどの程度熱湯中へ溶出するかを調べた (Table 3). 浸 出方法はそれぞれの製品に表示してある方法に従った.

乾燥葉 $\mathrm{A}$ 及び B の 2 製品について, それぞれ $2 \mathrm{~g}$ を 試料として $300 \mathrm{~mL}$ の熱湯に 5 分間浸出したところ, 試料中のバルバロインの浸出率は $75 \%$ 及び $90 \%$ と高 い值を示した．次に， A 製品について $10 \mathrm{~g}$ を煎じて飲 む場合のように, $500 \mathrm{~mL}$ の熱湯で 2 時間煮出し, 100 $\mathrm{mL}$ になるまで煮つめたところ, 浸出率は $67 \%$ と若干 低くなり, 分解あるいは揮散したことあ考えられる.

ティーバッグ状製品について，一袋を $1 \mathrm{~L}$ の熱湯で 8 分間浸出したところ，一袋中のバルバロインの浸出率は 80\%であった.

これらの結果から，製品中のバルバロインの多くは熱 湯へ溶出することが分かった.

\section{5. アロエ含有食品及び局方アロエ中のバルバロイン 含有量と摂取量の比較}

局方アロエは「緩下薬として 1 回 $0.125 \sim 0.25 \mathrm{~g}, 1$ 日 1〜3 回服用する」とされており，その鴧下効果はバ ルバロイン含量に比例する ${ }^{13), 20)}$. このことから, バル バロインを含むアロエ製品では摂取量によっては瀉下作
Table 4. Comparison of Contents of Barbaloin in Foods Containing Aloe and a Dose of Pharmacopoeial Aloe

\begin{tabular}{lcc}
\hline \hline \multirow{2}{*}{ Sample } & \multicolumn{2}{c}{ Barbaloin } \\
\cline { 2 - 3 } & $\begin{array}{c}\text { Contents } \\
(\mathrm{mg} / \mathrm{g})\end{array}$ & $\begin{array}{c}\text { Dose } \\
(\mathrm{mg})\end{array}$ \\
\hline Granulated product & 5.2 & $3.4^{\mathrm{a})}$ \\
Dried leaves product & 3.7 & $2.3^{\mathrm{b})}$ \\
Pharmacopoeial aloe & 57 & $7.1^{\mathrm{c})}$ \\
\hline
\end{tabular}

a) Total amount in 5 granules indicated as general standard intake for a day. The average weight of one granule was $0.13 \mathrm{~g}$.

b) The amount in an exudate $(100 \mathrm{~mL})$ during infusing of sample $(2 \mathrm{~g})$ in $90^{\circ} \mathrm{C}$ water $(300$ $\mathrm{mL}$ ) for $5 \mathrm{~min}$. Exude rate of this sample was $90 \%$.

c) The amount in a dose per once. A dose of the Japan Pharmacopoeia is $0.125 \sim 0.25 \mathrm{~g} /$ once.

用を示すことも考えられるため, 製品を利用する際の摂 取量及び局方了ロエの服用量における両者のバルバロイ ン含有量を比較し, Table 4 に示した.

バルバロイン含有量が $5.2 \mathrm{mg} / \mathrm{g}$ と最む多かった粒状 製品（一粒の平均重量; $0.13 \mathrm{~g}$ ) の場合, 製品に表示し てある摂取目安量の 5 粒中には $3.4 \mathrm{mg}$ のバルバロイン を含むことになる. 一方, 今回用いた局方アロエ（バル バロイン含有量； $57 \mathrm{mg} / \mathrm{g}$ ）の場合, その一回の服用 量 $(0.125 \mathrm{~g})$ から換算するとバルバロインを $7.1 \mathrm{mg}$ 摂 取することになる.そこで，これらのバルバロイン量の 比較から摂取目安量の約 2 倍の $10 \sim 11$ 粒を摄取する と，人によっては滨下作用を示す恐れがある.

次に，バルバロイン含有量が $3.7 \mathrm{mg} / \mathrm{g}$ であった乾燥 葉製品を熱湯で浸出 $(2 \mathrm{~g} \rightarrow$ 熱湯 $300 \mathrm{~mL}$. 浸出率; 90\%) した場合では, 一杯 $(100 \mathrm{~mL})$ 当たり $2.3 \mathrm{mg} の$ バルバロインを含むことになり, 前述のように局方アロ エの服用量との比較から，この浸出液の 3 杯程度を飲 むと人によっては，瀉下作用を示すことが考えられる.

これらの結果から, バルバロインを多く含む製品では 一般的な摂取量の $2 \sim 3$ 倍量を摄取するだけで, 鴧下作 用を発現する量に達するものと推察された. 


\section{ま と め}

アロエを素材とする健康食品 5 種 15 試料について, アロエの成分のうち瀉下作用を持つバルバロインの含有 量及び飲料製品中での安定性, 乾燥葉製品及びティー バッグ製品における熱湯浸出による挙動を調査した.

その結果，バルバロイン含有量は粒状製品で $2.9 \sim 5.2$ $\mathrm{mg} / \mathrm{g}$, 粉末製品で $5.0 \mathrm{mg} / \mathrm{g}$ 及び乾燥葉製品で 3.7 及 び $4.2 \mathrm{mg} / \mathrm{g}$ と高い值が得られた.

飲料製品中のバルバロインは, 酸性状態であ冷暗所で の 1 か月放置で $50 \%$ 以下に減少していた.

乾燥葉製品を熱湯で浸出した場合, 製品中のバルバロ インは大部分が熱湯中へ溶出することが分かった.

また，製品中のバルバロイン含有量を局方アロエの服 用量と比較したところ, バルバロインを多く含む製品で は摄取目安量の $2 \sim 3$ 倍量を摄取するだけで, 下風的作 用を示す可能性があることが分かった.

これらのことからアロエ含有食品を利用する消費者の ために，摂取量に対する注意を促す表示をすることあ必 要と思われる.

文献

1) 安田和男, 西島基弘, 斎藤和夫, 上村 尚, 井部明広, 永山敏廣, 牛山博文, 田端節子, 松本幸子, 直井家壽太, 二島太一郎：食衛誌. $25,371 \sim 377$ (1984).

2) 安田和男, 西島基弘, 斎藤和夫, 上村 尚, 井部明広, 永山敏廣, 牛山博文, 田端節子, 直井家壽太, 二島太一 郎: 同上 27, 302 310 (1986).

3）只野敬子, 安田和男, 牛山博文, 二島太一郎：同上 32 , 402 407 (1991).

4）難波恒雄編：“原色和漢薬図鑑（下）” p. 218～221 (1986) 保育社.

5) 刈米達夫，木村康一監修：“薬用植物大事典” p. $23 \sim 24$
(1966) 廣川書店.

6) 添田百枝：東邦医会誌. 16, 365 369 (1969).

7) Yagi, A., Makino, K., Nishioka, I., Kuchino, Y.: Planta Med. 31, 17 20 (1971).

8) Hirata, T., Suga, T.: Bull. Chem. Soc. Jpn. 51, $842 \sim$ 849 (1978).

9) Suzuki, I., Saito, H., Inoue, S., Migita, S., Takahashi, T.: J. Biochem. 85, 163 171 (1979).

10）亀山省司：フレグランスジャーナル 60,101〜106 (1983).

11) Yamamoto, M., Sugiyama, K., Yokota, M., Maeda, Y. Nakagomi, K., Nakazawa, H.: 衛生化学 39, 395 400 (1993).

12) Yamamoto, M., Masui, T.: Agric. Biol. Chem. 55, 1,627 $\sim 1,629$ (1991).

13）石井康子, 谷澤久之, 池本長司, 滝野吉雄：薬誌. 101, 254 258 (1981).

14）山本政利, 石川雅章, 増井俊夫：静岡県衛生環境セン 夕一報告 28, 35 39 (1985).

15) Yamamoto, M., Ishikawa, M., Masui, T., Nakazawa, H., Kabasawa, Y.: J. Assoc. Anal. Chem. 68, 493 494 (1985).

16) Grun, M., Franz, G.: Pharmazie 34, 669 670 (1979).

17) Graf, E., Alexa, M.: Planta Med. 38, 121 127 (1980).

18) Autenhoff, H., Graf, E., Eurisch, G., Alexa, M.: Arch. Pharm. (Weinheim) 313, 113 120 (1980).

19) 山本政利, 石川雅章, 增井俊夫, 中澤裕之, 藤田昌彦, 中込和哉：食衛誌. 26, 600 604 (1985).

20）日本公定書協会編：“第十二改正日本薬局方解説書” D-47 $\sim \mathrm{D}-51$ (1991) 廣川書店.

21）厚生省薬務局監視指導課長通知：“無承認無許可医薬品の 監視指導について”昭和 62 年 9 月 22 日薬監第 88 号 (1987). 